\title{
The agent, state-space model of the mobile robot
}

\author{
Krzysztof Oprzędkiewicz, Maciej Ciurej, Maciej Garbacz \\ AGH Akademia Górniczo-Hutnicza, Wydział Elektrotechniki, Automatyki, Informatyki i Inżynierii Biomedycznej, al. A. Mickiewicza 30, 30-059 Kraków
}

\begin{abstract}
The paper is devoted to present a new agent model of wheeled mobile robot. The proposed model based on nonlinear state space, discrete model of kinematics and employes Braitenberg algorithm to control the robot during move to target with passing obstacles. As a real robot the Khepera robot with IR proximity sensors was considered. The proposed agent model can be generalized onto another similar classes of devices. Results of experiments show that the proposed model correctly describes the behaviour of real device during realization of different jobs, for example obstacle passing.
\end{abstract}

Keywords: mobile robot, trajectory planning, agent model, design pattern, Braitenberg algorithm

\section{Introduction}

Trajectory planning in unknown environment is one of the crucial problems in mobile robotics. Mobile robot trajectory planning under constraints for partial and full coverage of given field was considered in [3]. Braitenberg algorithm based trajectory planning was considered in [5]. Specific case of path planning in picture drawing application was described in [10]. Following predefined trajectory autonomous robot in indoor transportation was presented in [11]. Same authors considered also manipulator trajectory of reconfigurable mobile robot in [12]. Quantum behaved Particle Swarm Optimization approach in trajectory planning was presented in [13].

The use of agent-based approach in modeling of mobile robots is caused by the fact that mobile robot interacts with unknown environment and often co-operates with another devices. This approach employes also well-known architecture and design patterns, able to describe different systems independently on technical details. The embodied agent model is typically decomposed to functional subsystems, which can be described independently. Additionally, the simple agent can be also easily employed to modeling a team of cooperating agents.

This approach has been considered by many authors, for example [1] where authors considered multi-agent systems where each agent has another specified task to accomplish. Person-following robot modeling case with the use of agent-based approach has been described in [6]. Fundamental for this paper use and

Autor korespondujący:

Krzysztof Oprzędkiewicz, kop@agh.edu.pl

Artykuł recenzowany

nadesłany 10.07.2018 r., przyjęty do druku 27.08.2018 r. definition of embodied-agent has been introduced in [14-16]. Fundamentals of control algorithm employed in this paper have been given by Braitenberg [2], the Braitenberg algorithm has been also discussed in [4]. The broad study about models of mobile robots has been given in [9].

Typically, agent models of mobile robots use artificial intelligence (AI) methods: knowledge engineering, knowledge based models, neural networks etc. The verification and validation this class of models requires a big number of experimental data and a huge number of calculations. The authors of this paper do not know agent-based model employing state space approach. The state-space model of robot kinematics is most accurate and it allows to analyse the fundamental properties: stability and controllability with the use of well-known mathematical tools and results of this analysis are accurate and unique.

This paper is intented to propose a new, agent based model of two wheeled mobile robot. The proposed approach employes the nonlinear, discrete state space model describing the kinematics of the Khepera III robot with IR proximity sensors, proposed in [5]. The work of IR proximity sensors is described by the interval Mittag-Leffler function (see [8]). The job of the robot under consideration is to drive from starting point to target with passing unknown obstacles detected by sensors or detect and reach an attractor, which localization is not exactly known. Additionally the robot is required to work correctly when some of sensors do not work properly.

The approach proposed in this paper bases on general, agent model of a robotic system given in paper [16]. It is able to describe different classes of robots and its idea consists in divide the robot into main functional parts realizing partial jobs associated to main job executed by a robot. Generally there are receptors, effectors and control system, connected in order to realize certain jobs. Algorithm realized by each part of agent is described by a state graph and transition functions. The work of robot determined by different conditions (for example: typical work and error detection) is expressed by behaviours.

The paper is organized as follows: at the beginning some preliminaries are given and the state space model of robot kine- 
matics is presented. Next the proposed agent model of the robot under consideration is given. Finally the simulations covering the ride of robot to target with passing obstacles presented and going to attractor are and discussed.

\section{Preliminaries}

\subsection{Braitenberg algorithm}

The fundamental algorithm for control of simple two wheeled vehicle has been proposed by Braitenberg [2]. Its idea consists in direct connection between sensors and actuators. Each connection has got assigned some weight. Its "classic" version does not assume the motion to target but in real case this needs to be always considered. This implies that in further considerations the modified algorithm will be employed. The scheme of robot moving with the use of the modified algorithm is shown in figure 1.

\subsection{State-space kinematics model of the considered mobile robot}

The proposed state space model is required to describe Khepera III mobile robot equipped with IR proximity sensors employed to recognize the environment and localize obstacles. The state-space model of its kinematics has been proposed and analysed in [5]. Localization of drives and sensors for the considered robot is shown in figures 2 and 3 .

Kinematics equation describing a motion of robot is defined as follows:

$$
\left[\begin{array}{c}
\dot{x} \\
\dot{y} \\
\dot{\theta} \\
\dot{\varphi}_{1} \\
\dot{\varphi}_{2}
\end{array}\right]=\left[\begin{array}{cc}
\sin \theta & 0 \\
\cos \theta & 0 \\
0 & 1 \\
\frac{-1}{r} & \frac{-l}{r} \\
\frac{1}{r} & \frac{-l}{r}
\end{array}\right] \cdot\left[\begin{array}{l}
u_{1} \\
u_{2}
\end{array}\right]
$$

where: $x, y$-current position the center of robot in global coordinate system, $\theta$ - angle between local coordinate system involved with robot and global coordinate system, $\varphi_{1}, \varphi_{2}$ - angle position of left and right wheel of robot, $u_{1}$ - linear speed of robot, $u_{2}$ - speed of change robot orientation, $l$ - half of distance between two wheels, $r$-radius of robot wheel.

It is possible to formulate the state equation for speeds $u_{1}$ and $u_{2}$ :

$$
\begin{gathered}
u_{1}=r \cdot \frac{\dot{\varphi}_{2}-\dot{\varphi}_{1}}{2} \\
u_{2}=-r \cdot \frac{\dot{\varphi}_{2}+\dot{\varphi}_{1}}{2}
\end{gathered}
$$

After transformation (1) we obtain formula between constituent of whole robot velocity and velocity of each wheel

$$
\left[\begin{array}{c}
\dot{x} \\
\dot{y} \\
\dot{\theta}
\end{array}\right]=\left[\begin{array}{cc}
\frac{r \cdot \sin \theta}{2} & \frac{-r \cdot \sin \theta}{2} \\
\frac{-r \cdot \cos \theta}{2} & \frac{r \cdot \cos \theta}{2} \\
\frac{-r}{2} & \frac{-r}{2}
\end{array}\right] \cdot\left[\begin{array}{c}
\dot{\varphi}_{1} \\
\dot{\varphi}_{2}
\end{array}\right]
$$

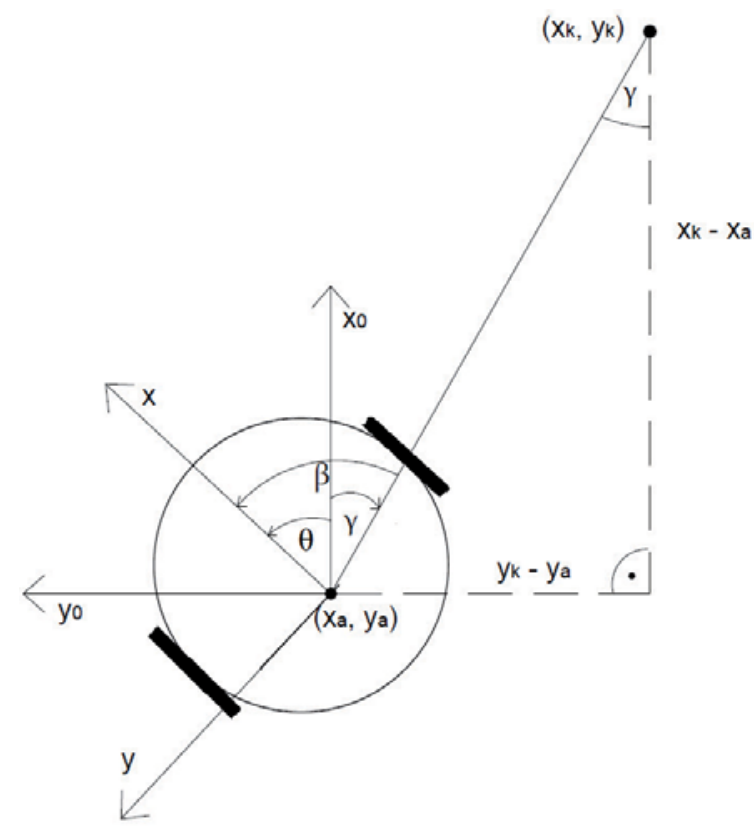

Fig. 1. Modified Braitenberg algorithm

Rys. 1. Zmodyfikowany algorytm Braitenberga

With respect to modified Braitenberg algorithm, velocities of each wheel are described as follows:

$$
\begin{gathered}
\omega_{L}=\sum_{n=1}^{4} \omega_{n} u_{n}-\sum_{n=5}^{8} \omega_{n} u_{n}+K+M \beta \\
\omega_{R}=-\sum_{n=1}^{4} \omega_{n} u_{n}+\sum_{n=5}^{8} \omega_{n} u_{n}+K-M \beta .
\end{gathered}
$$

where $\mathrm{M}$ is the weight of coefficient responsible for correct wheels velocity due to deviation between current direction of robot motion and straight line getting across the center of robot and target point, $\beta$ is the angle between current direction of robot motion and straight line getting across the center of robot and target point, $K$ is the base velocity of each wheel. It is necessary to assure the motion of the robot when there are no obstacles detected by sensors. In the figure 1 it can be noted that:

$$
\begin{gathered}
\beta=\theta-\gamma \\
\gamma=\arctan \frac{y_{k}-y}{x_{k}-x} . \\
\theta=r\left(\sum_{n=1}^{4} \omega_{n} u_{n}-\sum_{n=5}^{8} \omega_{n} u_{n}+M \beta\right) . \\
\theta=r\left(\sum_{n=1}^{4} \omega_{n} u_{n}-\sum_{n=5}^{8} \omega_{n} u_{n}+M \theta-M \arctan \frac{y_{k}-y}{x_{k}-x}\right) .
\end{gathered}
$$

In the case of defined target (modified Braitenberg algorithm) the following relationship is kept:

$$
\boldsymbol{\theta}=\grave{\mathbf{u}}=r\left(\sum_{n=1}^{4} \omega_{n} u_{n}-\sum_{n=5}^{8} \omega_{n} u_{n}+M \theta-M \arctan \frac{y_{k}-y}{x_{k}-x}\right)
$$

Finally the model of robot kinematics with defined target takes the form as below: 


$$
\left\{\begin{array}{l}
\dot{x}=\frac{K r}{l} \cos \theta \\
\dot{y}=\frac{K r}{l} \sin \theta \\
\theta=r\left(\sum_{n=1}^{4} \omega_{n} u_{n}-\sum_{n=5}^{8} \omega_{n} u_{n}+M \theta-M \arctan \frac{y_{k}-y}{x_{k}-x}\right)
\end{array} .\right.
$$

The robot path calculated as solution of (8) is required to meet the following constraints:

1. start from point $\left(0,0, \theta_{0}\right)$,

2. finish in point $(x, y, \theta)$,

3. cannot across any obstacle.

In order to proceed with further investigation, there is a need to transform continuous-time non-linear equation (8) to its discrete version. The simplest way to do it is to apply the Euler backward difference: $\dot{x} \cong \frac{x(k)-x(k-1)}{h}$. If the nonlinear model in continuous time scope is described by (8), then the discrete state of the agent ${ }_{r}^{e} c^{k}$ takes the following form:

$$
{ }_{r}^{e} c^{k}=[x(k), y(k), \theta(k)]^{\mathrm{T}}
$$

where:

$$
\begin{cases}x(k)=x(k-1)+\frac{h K r}{l} \cos \theta(k-1) & \text { Fig. 3. Sensors co } \\ y(k)=y(k-1)+\frac{h K r}{l} \sin \theta(k-1) & \text { Rys. 3. Konfiguracja } \\ \theta(k)=h r\left(\sum_{n=1}^{4} \omega_{n} u_{n}(k-1)-\sum_{n=5}^{8} \omega_{n} u_{n}(k-1)+M \theta(k-1)-M \arctan \frac{y_{k}-y(k-1)}{x_{k}-x(k-1)}\right) .\end{cases}
$$

In (10) $h$ denotes the sample time, $k$ denotes discrete time moments. The nonlinear, discrete state equation (10) directly connects signals read by IR sensors with control signals sent to drives. It can be utilized to construct the agent model of the considered robot with respect to formal approach given in [16]. This will be shown in the next section.

\section{The proposed agent model}

The agent model of Khepera robot shown in figures 1 and 3 can be presented as the following set:

$$
A=\left\{P_{n}, E_{m}, p_{n}, e_{m}, c, f\right\}
$$

where $P$ and $E$ are real receptors and effectors, $p$ and $e$ are sets of virtual receptors and effectors, $c$ is a control system and $f$ is a nonlinear transition function.

Real receptors $P_{n}, n=1, \ldots, 8$ are IR sensors, real effectors $E_{R, L}$ are the angular velocities of wheels (index $R$ denotes the right wheel, $L$ denotes left one), the control subsystem is described by a nonlinear transition function, derived from state equation (8) after necessary transformations.

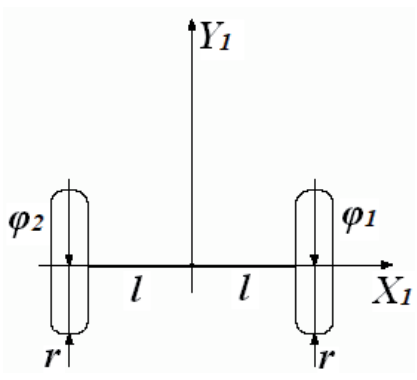

Fig. 2. Drive configuration in the considered robot Rys. 2. Konfiguracja napędów w rozważanym robocie

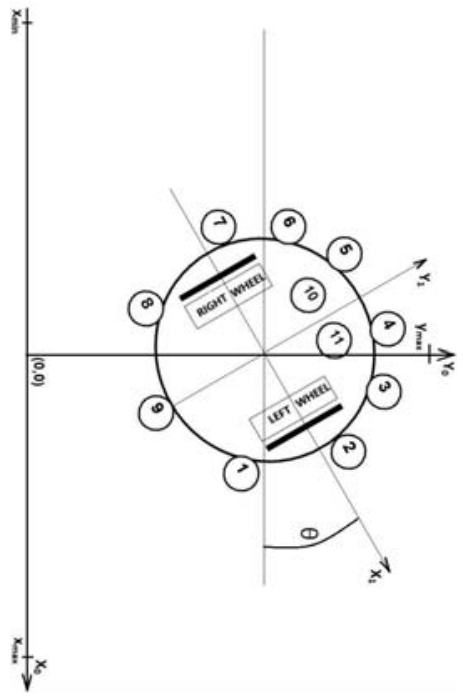

The dependence between real and virtual receptors in the $k$-th time moment is following:

$$
{ }_{P}^{c} p_{n}^{k}=\left(\sum_{n=1}^{4} \omega_{n} P_{n}^{k}-\sum_{n=5}^{8} \omega_{n} P_{n}^{k}\right), \quad n=1, \ldots, 8 .
$$

Next the transition function $f$ needs to be defined. It has 3 components, associated with state variables in equation (10):

$$
f^{k}=\left[f_{x}^{k}, f_{y}^{k}, f_{\theta}^{k}\right]^{\mathrm{T}}
$$

where:

$$
\begin{aligned}
& f_{x}^{k}=x(k) \\
& f_{y}^{k}=y(k) \\
& f_{\theta}^{k}=\theta(k)
\end{aligned}
$$

With respect to (10) the transition function takes the following form: 


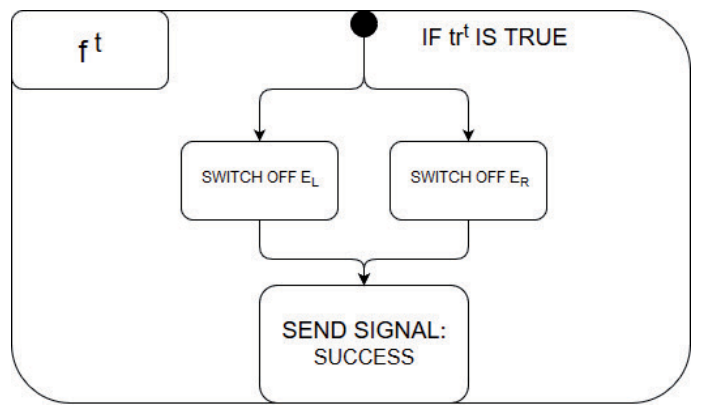

Fig. 4. Arrival to target function

Rys. 4. Funkcja osiągnięcia celu

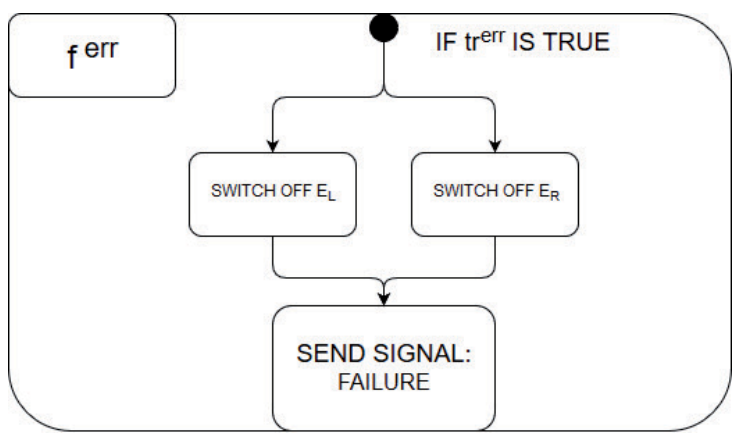

Fig. 5. Error function

Rys. 5. Funkcja błędu

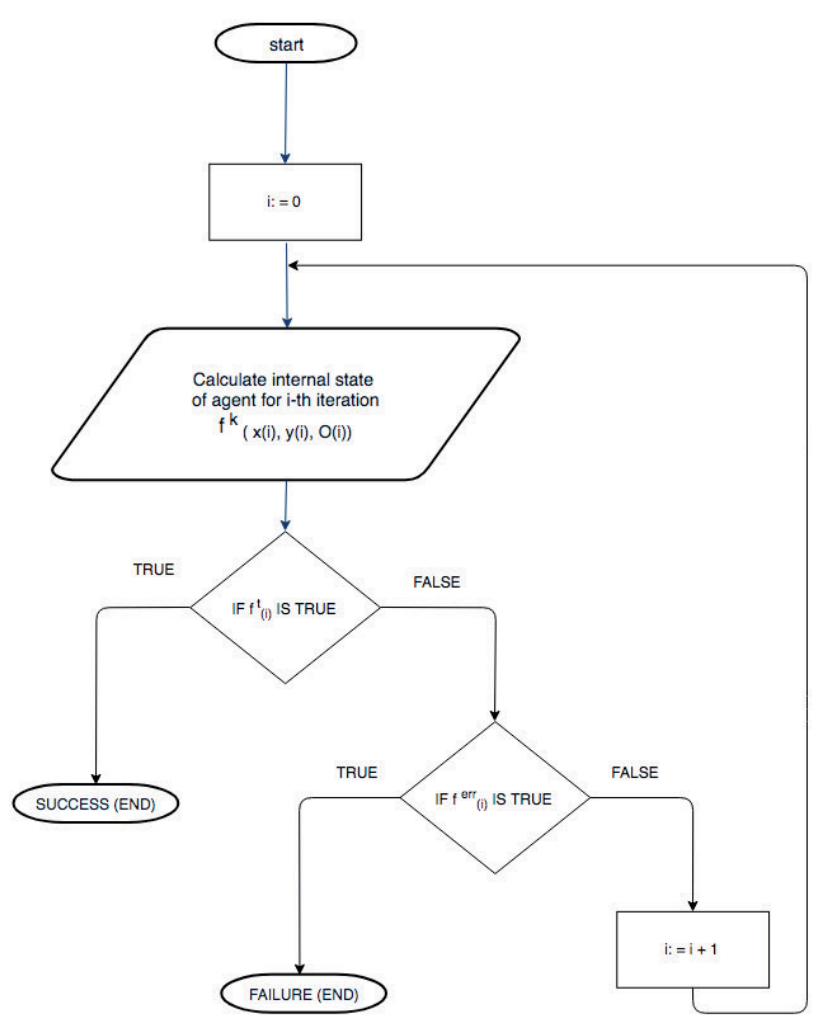

Fig. 6. Flow chart of system behavior

Rys. 6. Schemat blokowy zachowania się systemu

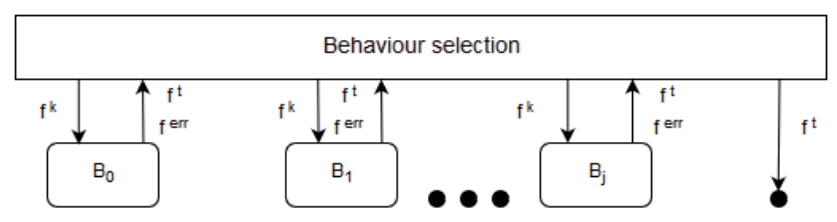

Fig. 7. State graph for considered system Rys. 7. Graf stanu dla rozważanego systemu

$$
\left\{\begin{array}{l}
f_{x}^{k}=f_{x}^{k-1}+\frac{h K r}{l} \cos f_{\theta}^{k-1} \\
f_{y}^{k}=f_{y}^{k-1}+\frac{h K r}{l} \sin f_{\theta}^{k-1} \\
f_{\theta}^{k}=h r_{P}^{c} p_{n}^{k}+M f_{\theta}^{k-1}-M \arctan \frac{f_{y}^{k}-f_{y}^{k-1}}{f_{x}^{k}-f_{x}^{k-1}}
\end{array}\right.
$$

The virtual effectors ${ }_{c}^{E} e_{n}^{k}$ in $k$-th moment are following:

$$
\begin{aligned}
& { }_{c}^{E} e_{L}^{k}=\sum_{n=1}^{4} \omega_{n} p_{n}^{k}-\sum_{n=5}^{8} \omega_{n} p_{n}^{k}+K+M \beta \\
& { }_{c}^{E} e_{R}^{k}=\sum_{n=1}^{4} \omega_{n} p_{n}^{k}+\sum_{n=5}^{8} \omega_{n} p_{n}^{k}+K-M \beta
\end{aligned}
$$

Real effectors are directly equal to virtual:

$$
{ }_{e} E_{m}^{k}={ }_{c}^{E} e_{m}^{k}, \quad m=R, L .
$$

The job of the robot is to drive from starting point $c^{0}$ to target $c^{\tau}$ with passing unknown obstacles. This job cannot be realized, if an obstacle is not possible to pass. This can should be defined as an anomalous situation. Consequently the behaviour $B$ of the considered robot can be expressed by 3 functions:

$$
B=\left\{f^{d}, f^{\tau}, f^{e r r}\right\}
$$

In the first one $f^{d}=f^{k}$ describes the ride of robot with successful passing obstacles, the next one $f^{\tau}$ defines activities in case of arrival to target and the last one $f^{e r r}$ describes situation, when obstacle cannot be passed.

Definitions of $f^{\tau}$ and $f^{e r r}$ are presented accordingly in figures 4 and 5 .

In case of both functions, there is a need to define triggers which are responsible for execute those functions when specific event (condition of agent) will be observed. Condition which triggers arrival to target function $\left(t r^{t}\right)$ is defined as follows:

$$
t r^{t}=\sqrt{\left(f_{x}^{k}-x(0)\right)^{2}+\left(f_{y}^{k}-y(0)\right)^{2}} \leq d
$$

Where $d$ is arbitrary defined value which indicates maximal distance of robot from the target. Condition which triggers error state of considered agent $\left(t r^{e r r}\right)$ is defined as follows:

$$
t r^{e r r}=f_{x}^{k}-f_{x}^{k-1}=f_{y}^{k}-f_{y}^{k-1}=f_{\theta}^{k}-f_{\theta}^{k-1}=0
$$

When lack of any movement (of robot) between last and current state has been confirmed, error behaviour is executed.

General flow chart of considered system behaviour is presented in figure 6. State graph of the behaviour selection automaton is presented in figure 7 . Inner structure of agent considered for Khepera robot was prepared with the manner described in [16] and is presented in figure 8.

The above, nonlinear, discrete time agent based model can be employed to modeling of the behaviour of the considered mobile robot. It can be verified with the use of simulations. This will be shown in the next section. 


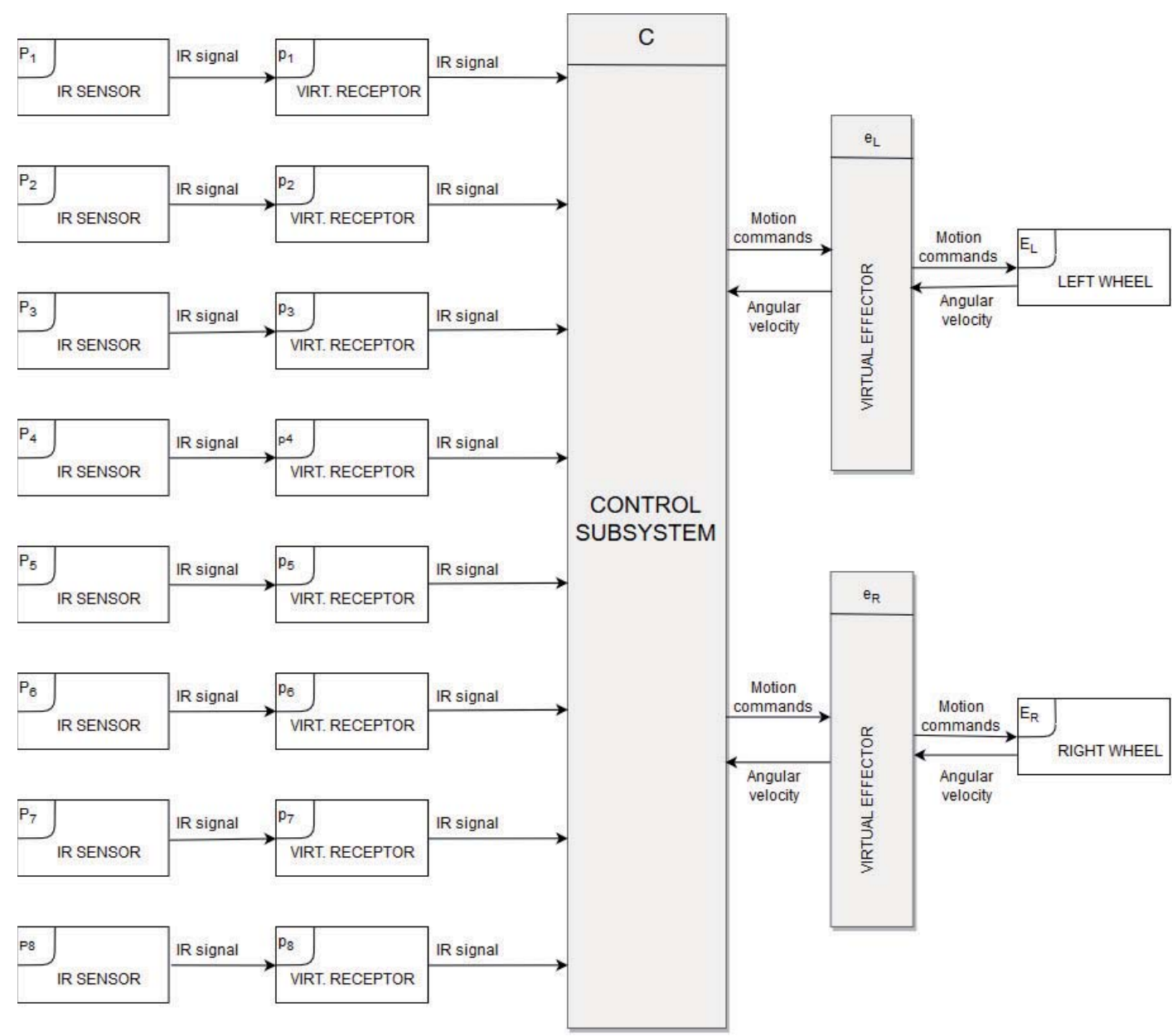

Fig. 8. Structure of considered agent representing robot Khepera

Rys. 8. Struktura agenta reprezentującego robot Khepera

\section{Simulations}

Simulations were done using the discrete agent model expressed by (10) and Simulink model shown in figure 9. Results of simulations with defined target are illustrated by figures 10 , 11, 12 and 13. Results of simulations with single attractor as target are illustrated by figures 14, 15, 16 and 17 .

Simulink model presented in figure 9 accepts two vectors as parameters: $w$ weights of sensors in considered system and $\mathrm{u}$ value detected by specified sensor. Outputs of described model are calculated local coordinates of considered robot $(x, y)$.

Simulations with defined target covers two types of obstacle shapes: circle and wall (oblong shape) and two types of colors: black and white. Reflection of infrared is much lower in case of black obstacle than in case of white obstacle.

Accordingly simulations with black colored obstacles presented in figures 11 and 13, occurs to calculate mobile robot trajectory in a way, which is interfering with position of placed obstruction object. Tests with a clear path of calculated trajectory are presented in figures 10 and 12 .

From the above figures it can be concluded at once that the color of the obstacle can significantly disturb the correct work of the robot we deal with. This is caused by the idea of work IR proximity sensors applied in the considered robot. The black obstacle absorbs radiation emitted by sensor and the robot is not able to correctly recognize it. It was also observed during experiments with real robot (see [5]).
In case of simulations covering single attractor as potential target it can be noticed that trajectory of mobile robot is calculated correctly. Weights determined by w parameter are key factors in this type of simulation. Having sufficient impact on proper $u$ value it makes model calculating suitable path in considered environment. It can be noticed that size of obstacle has impact on calculated trajectory. In figures 16 and 17 presenting bigger size of obstacles, robot receptors are more efficient in finding nearest edge of considered shape.

\section{Final conclusions}

The main final conclusion from the paper is that the proposed agent model employing nonlinear, discrete state equation correctly describes the behaviour of the real mobile two wheeled robot. Problems with passing the black obstacle are also correctly modeled.

Searching for attractor in defined environment is also correctly modeled. This area of research can be still explored with the use of additional algorithms covering individual handling of weights for each input to the considered system. The another open problems from the presented area cover for example the modeling of cooperation a team of mobile robots described by the proposed model, work of robot with damaged sensors and so on. This will be considered by authors. 

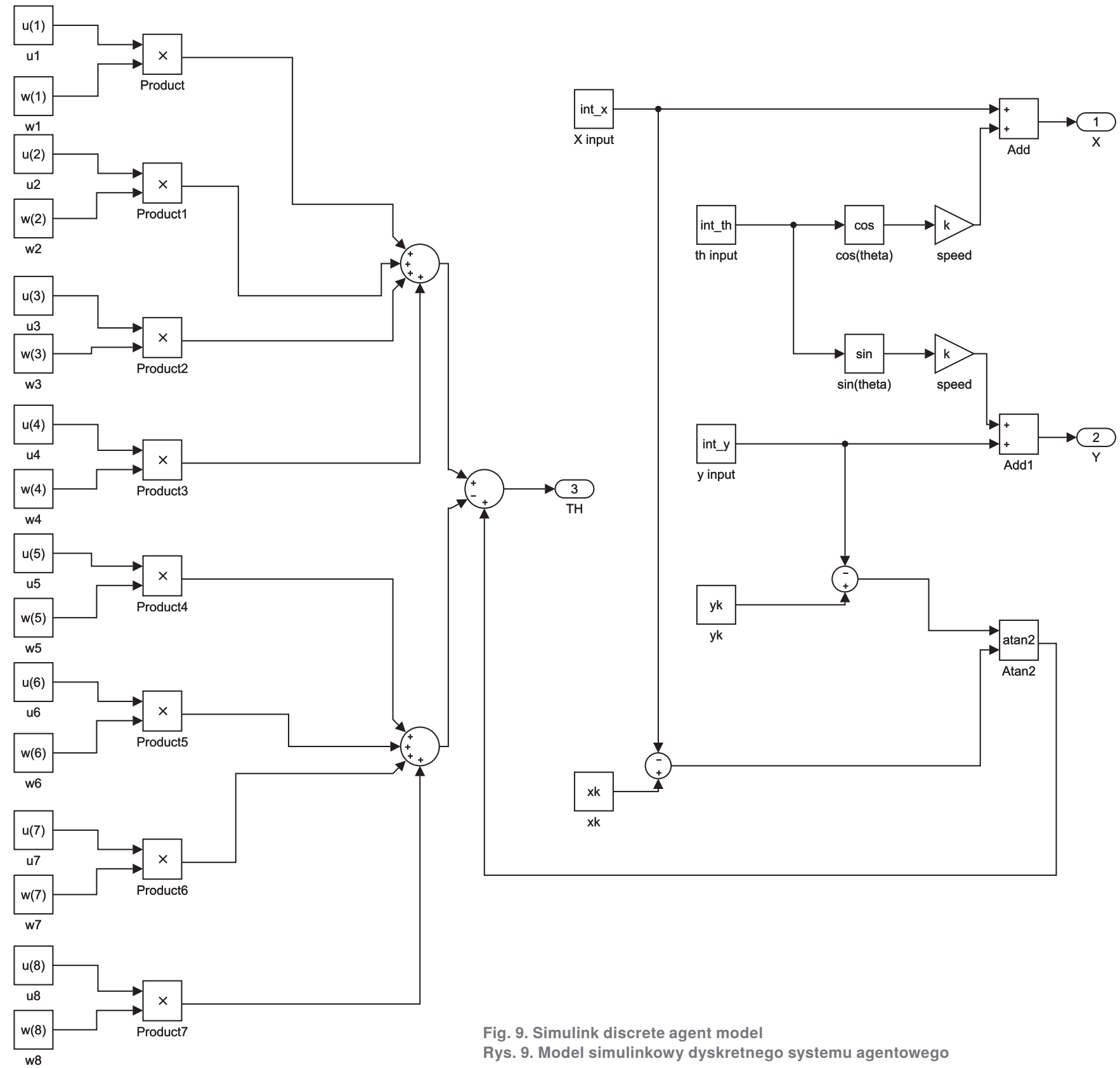

Fig. 9. Simulink discrete agent model

Rys. 9. Model simulinkowy dyskretnego systemu agentowego

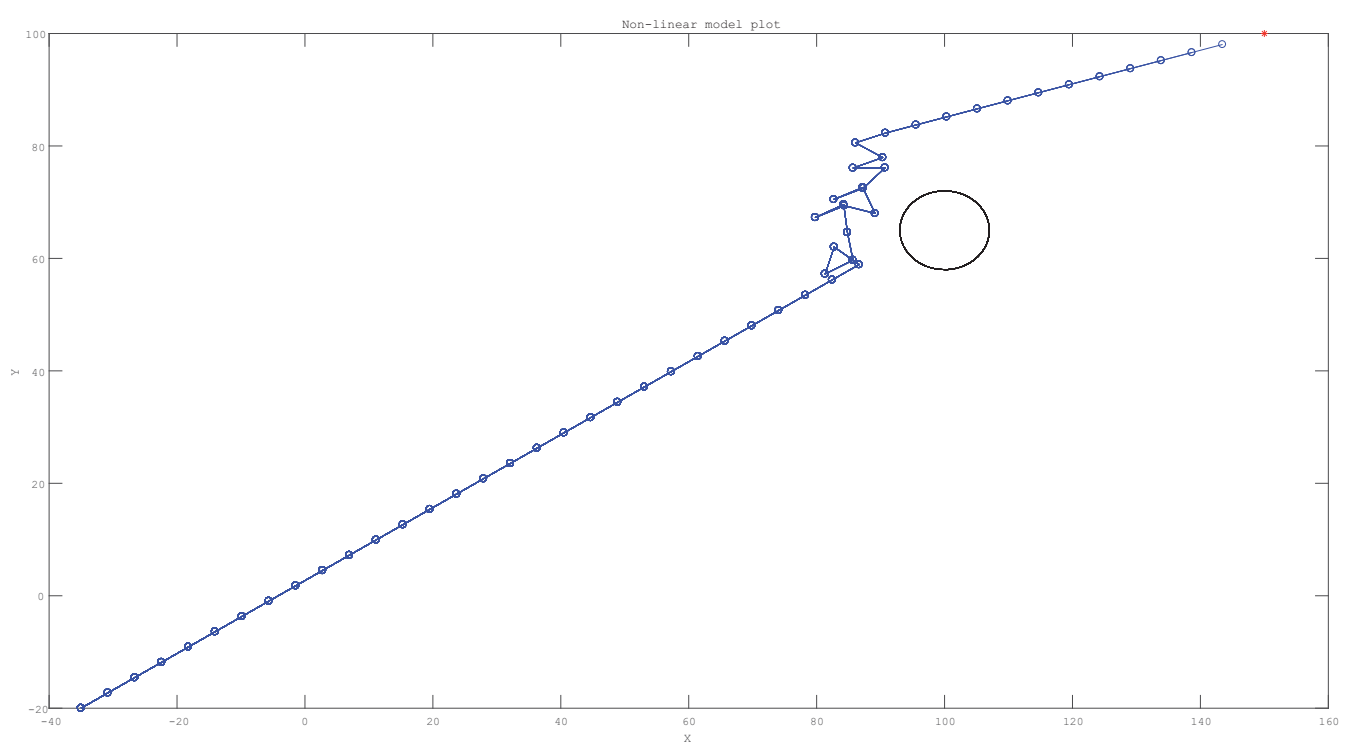

Fig. 10. Obstacle as white circle

Rys. 10. Test ominięcia przeszkody w postaci białego okręgu 


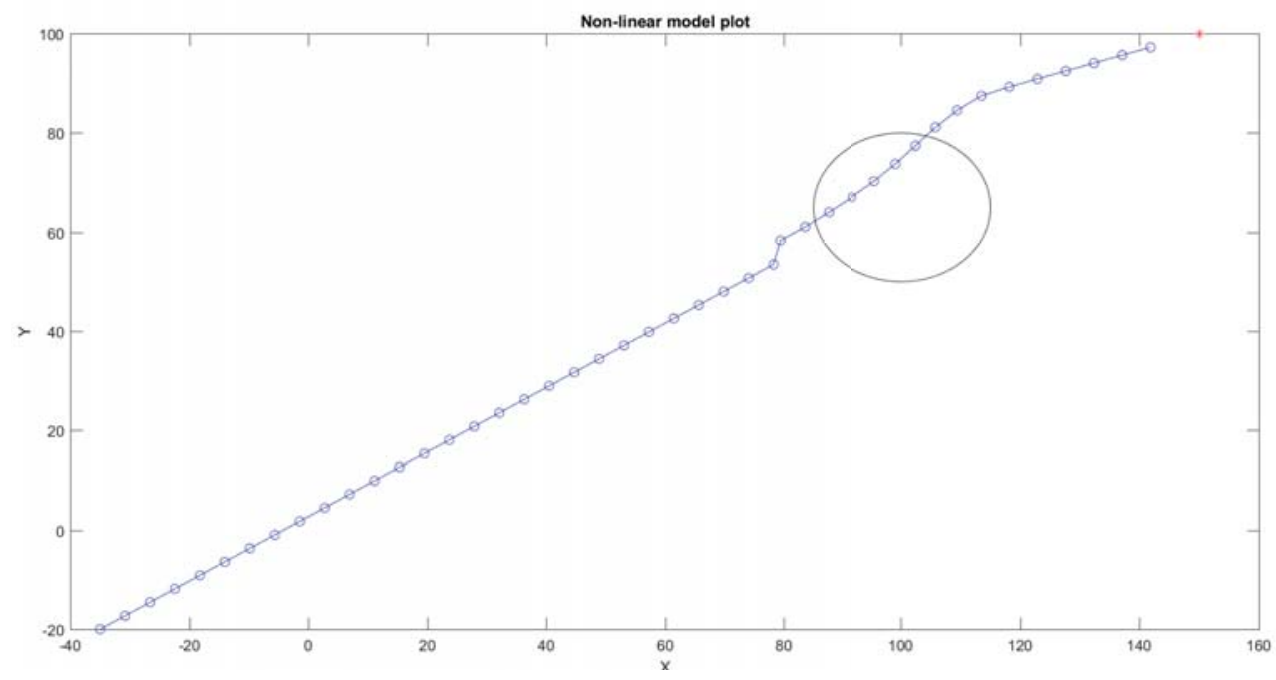

Fig. 11. Obstacle as black circle

Rys. 11. Test ominięcia przeszkody w postaci czarnego okręgu

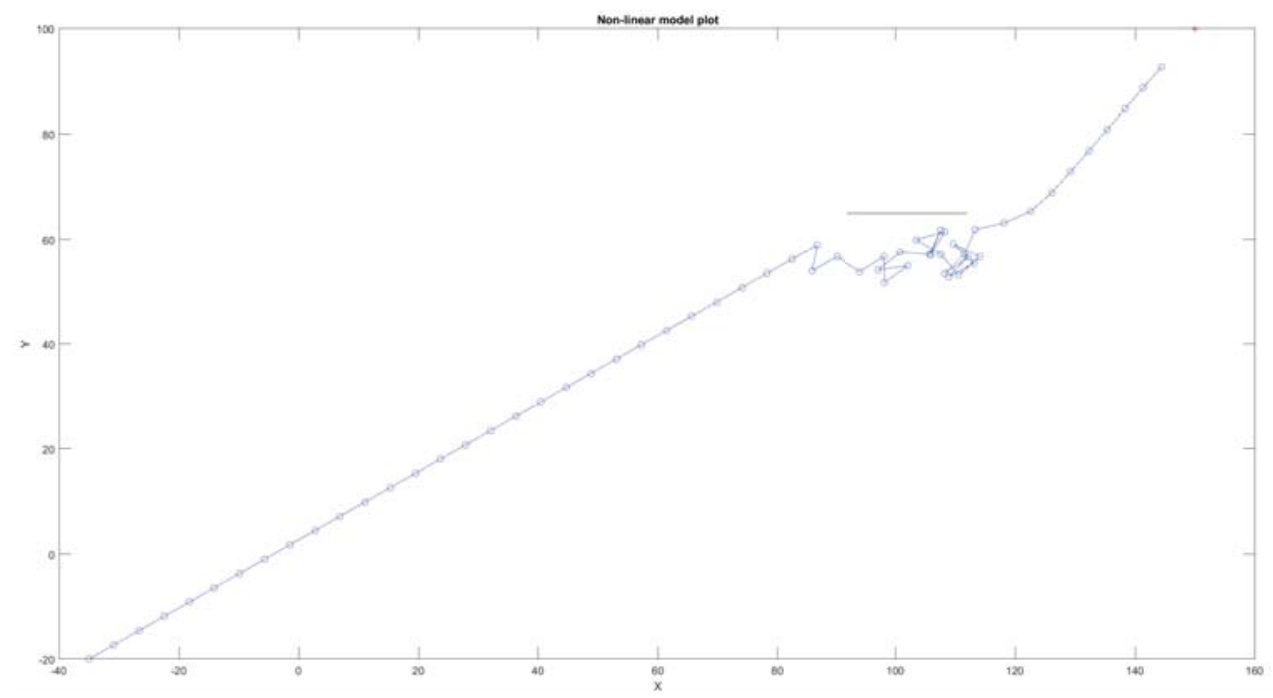

Fig. 12. Obstacle as oblong white shape

Rys. 12. Test ominięcia przeszkody w postaci białego kształtu

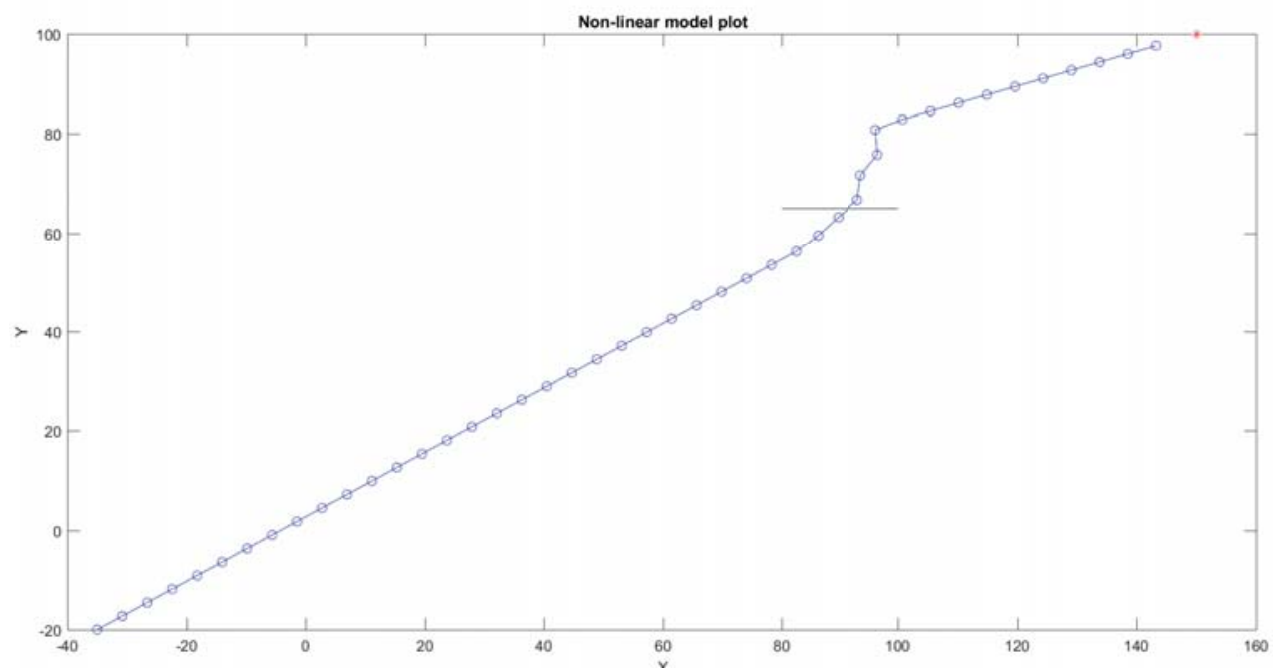

Fig. 13. Obstacle as oblong black shape

Rys. 13. Test ominięcia przeszkody w postaci czarnego kształtu 


\section{The agent, state-space model of the mobile robot}

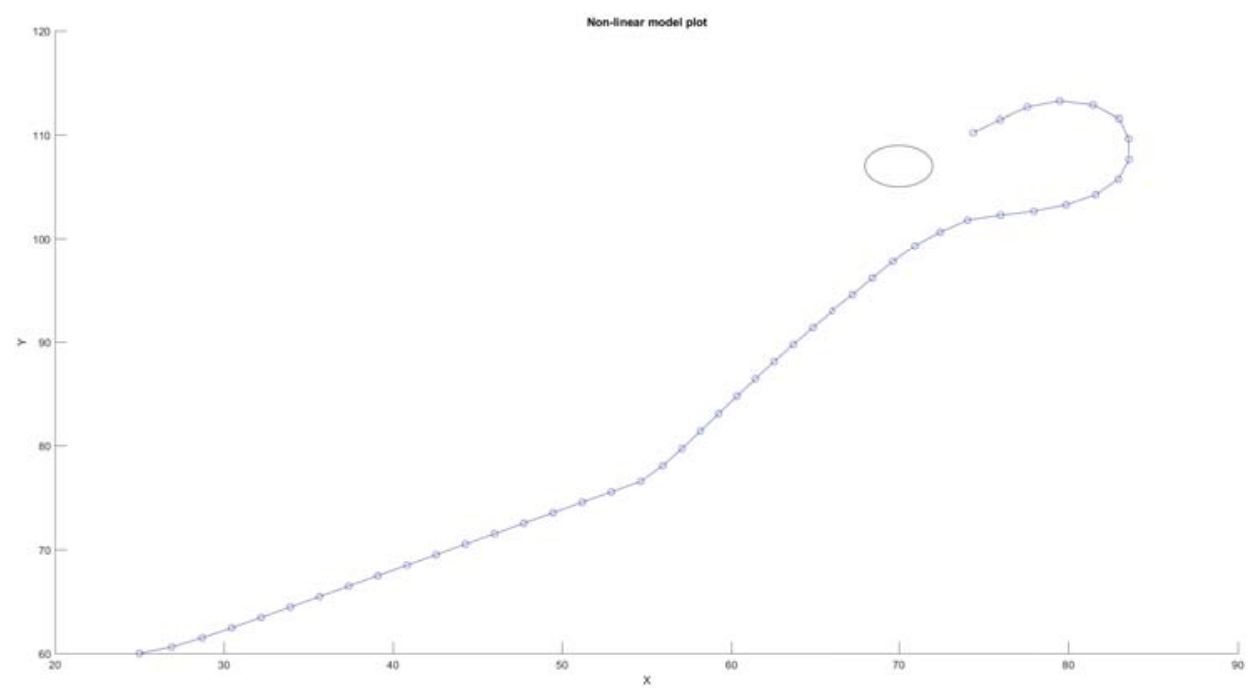

Fig. 14. Attractor as small circle

Rys. 14. Test jazdy do atraktora w postaci małego okręgu

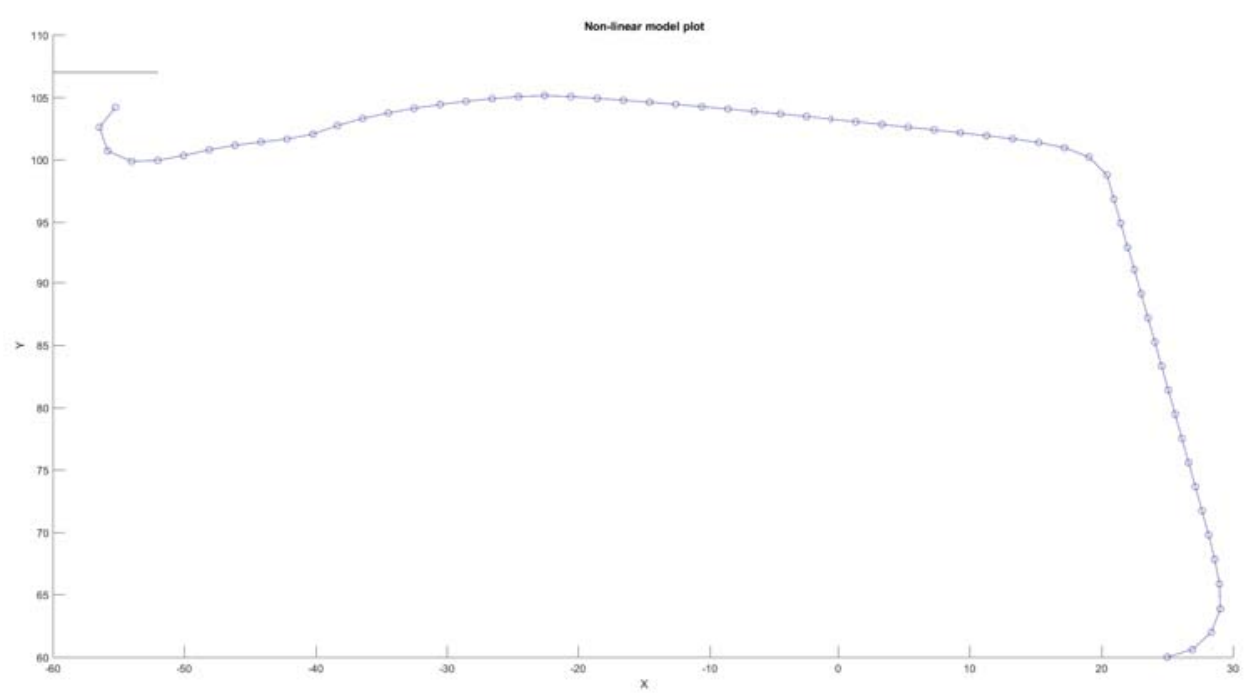

Fig. 15. Attractor as short oblong shape

Rys. 15. Test jazdy do atraktora w postaci małego podłużnego kształtu

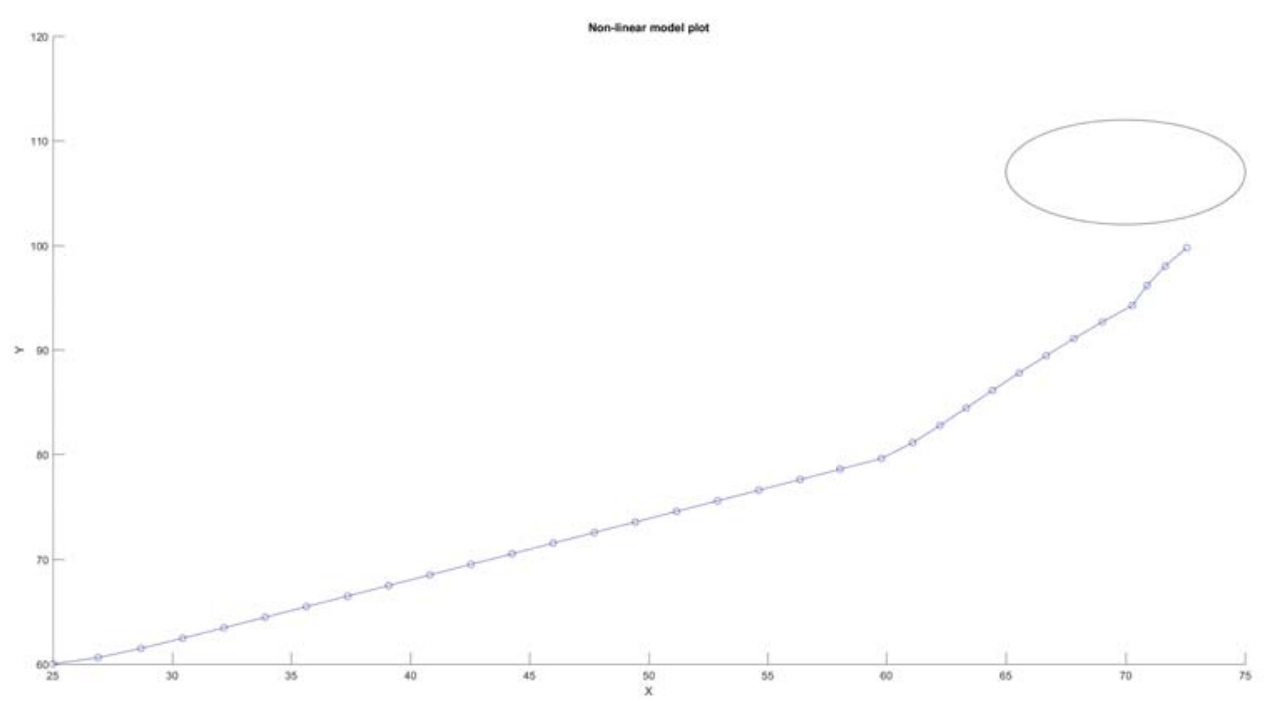

Fig. 16. Attractor as bigger circle

Rys. 16. Test jazdy do atraktora w postaci większego okręgu 


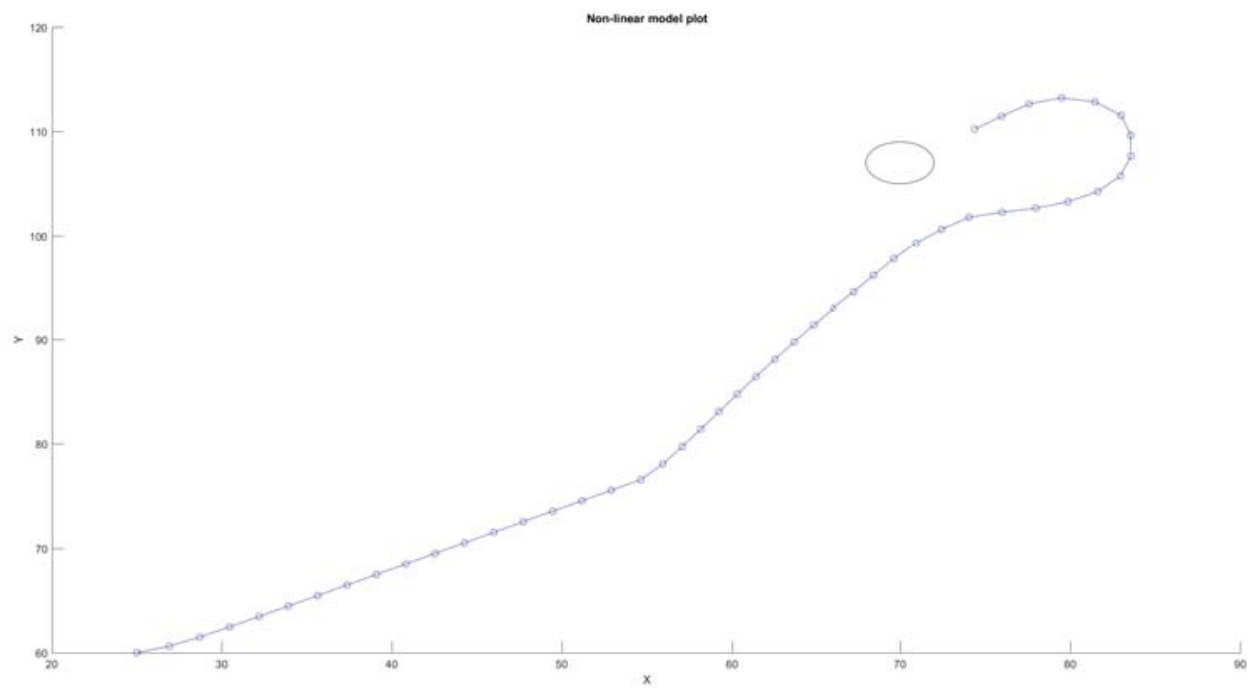

Fig. 17. Attractor as longer oblong shape

Rys. 17. Test jazdy do atraktora w postaci dużego podłużnego kształtu

\section{References}

1. Benaissa S., Moutaouakkil F., Medromi H., New Multi-Agent's Control Architecture for the Autonomous Mobile Robots, "International Review on Computers and Software", Vol. 6, No. 4, 2011, 477-480.

2. Braitenberg V., "Vehicles, experiments in synthetic psychology". Cambridge, MIT University Press Group Ltd., 1984.

3. Cariou C., Gobor Z., Seiferth B., Berducat M. (2017). Mobile Robot Trajectory Planning Under Kinematic and Dynamic Constraints for Partial and Full Field Coverage. "Journal of Field Robotics", Vol. 34, Iss. 7, 2017, 1297-1312, DOI: 10.1002/rob.21707.

4. Dumitrache I., Drâgoicea M. (2008) Agent-based Theory Applied in Mobile Robotics, "IFAC Proceedings Volumes", Vol. 41, Iss. 2, 2008, 13719-13724, DOI: 10.3182/200807065-KR-1001.02323.

5. Garbacz M., Path planning for the mobile robots from the point of view of its controllability, $\mathrm{PhD}$ dissertation at $\mathrm{AGH}$ University of Science and Technology, supervisor K. Oprzędkiewicz, Kraków 2016.

6. Gascueña J.M., Fernández-Caballero A., Agent-oriented modeling and development of a person-following mobile robot, "Expert Systems with Applications", Vol. 38, Iss. 4, 2011, 4280-4290, DOI: 10.1016/j.eswa.2010.09.096.

7. Nemeiksis A., Osadcuks V., (2017). Trajectory planning of mobile robot movement in unknown environment, [in:] Proceedings of Engineering for Rural Development, Jelgava, 24.26.05.2017, 1157-1166, DOI: 10.22616/ERDev2017.16.N247.

8. Oprzędkiewicz K., Garbacz M., Modeling of IR Proximity Sensors with the Use of Interval Mittag-Leffler Function. "Journal of Automation, Mobile Robotics and Intelligent Systems", Vol. 11, No. 3, 3-6, DOI: 10.14313/JAMRIS 3-2017/22

9. Płaskonka J., Different Kinematic Path Following Controllers for a Wheeled Mobile Robot of (2,0) Type. "Journal of Intelligent \& Robotic Systems", Vol. 77, Iss. 3-4, 2015, 481-498, DOI: 10.1007/s10846-013-9879-6.

10. Shih C., Lin L. (2017). Trajectory Planning and Tracking Control of a Differential-Drive Mobile Robot in a Picture Drawing Application, "Robotics", Vol. 6, Iss. 3, 2017, DOI: 10.3390/robotics6030017.
11. Wang W., Lei Z., Trajectory planning for a reconfigurable mobile robot in mobile manipulating mode. [in:] Proceeding of the $11^{\text {th }}$ World Congress on Intelligent Control and Automation, 2014, DOI: 10.1109/WCICA.2014.7052684.

12. Wang Y., Yang U., Wang S., Path tracking control of an indoor transportation robot utilizing future information of the desired trajectory. "International Journal of Innovative Computing, Information and Control", Vol. 14, No. 2, 2018, 561-572.

13. Xue T., Li R., Tokgo M., Ri J., Han G., Trajectory planning for autonomous mobile robot using a hybrid improved QPSO algorithm. "Soft Computing", Vol. 21, Iss. 9, 2015, 2421-2437, DOI: 10.1007/s00500-015-1956-2.

14. Zieliński C., Kornuta T., Trojanek P., Winiarski T., Method of Designing Autonomous Mobile Robot Control Systems. Part 1: Theoretical Introduction. "Measurement, Automation, Robotics" (Pomiary Automatyka Robotyka), 9/2011, 84-87 (in Polish).

15. Zieliński C., Kornuta T., Trojanek P., Winiarski T., Method of Designing Autonomous Mobile Robot Control Systems. Part 2: An Example. "Measurement, Automation, Robotics" (Pomiary Automatyka Robotyka), 10/2011, 84-90 (in Polish).

16. Zieliński C., Kornuta T., Winiarski T., A Systematic Method of Designing Control Systems for Service and Field Robots, [in:] $19^{\text {th }}$ IEEE International Conference on Methods and Models in Automation and Robotics, MMAR 2014, 1-14. 


\section{Agentowy model robota mobilnego w przestrzeni stanu}

Streszczenie: W artykule zaprezentowano nowy model agentowy kołowego robota mobilnego.

Proponowany model bazuje na nieliniowym równaniu stanu opisującym kinematykę robota

i wykorzystuje algorytm Braitenberga z zadanym punktem końcowym w celu omijania przeszkód. Jako przykład rzeczywistego robota rozważono robot Khepera III z czujnikami IR do wykrywania i omijania przeszkód. Zaproponowany model agentowy może być uogólniony na inne klasy podobnych urządzeń. Wyniki symulacji pokazują, że zaproponowany model dobrze opisuje zachowanie się rzeczywistego urządzenia podczas realizacji różnych zadań, np. przy omijaniu przeszkód.

Słowa kluczowe: robot mobilny, planowanie trajektorii, model agentowy, wzorce projektowe, algorytm Braitenberga

\section{Krzysztof Oprzędkiewicz, PhD DSc}

kop@agh.edu.pl

He was born in Krakow in 1964. He obtained MSc in electronics in 1988, PhD and DSc in Automatics and Robotics in 1995 and 2009 at AGH University of Science and Technology (Krakow, Poland). He has been working at AGH University in Department of Automatics since 1988, recently as a professor. In $2012-$ 2016 he was a deputy dean of faculty of Electrotechnics, Automatics, Informatics and Biomedical Engineering at AGH University. His

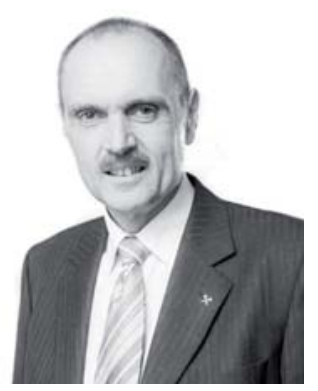
research covers infinite dimensional systems, fractional order modeling and control, uncertain parameter systems, industrial automation, PLC and SCADA systems, mobile robotics.

\section{Maciej Garbacz, PhD Eng.}

m.garbacz@agh.edu.pl

He received PhD degree in Automatic Control and Robotics from Faculty of Electrical Engineering, Automatics, Computer Science and Biomedical Engineering, AGH University of Science and Technology, Poland in 2016. Now he works at Department of Automatic Control and Robotics. His scientific interests focus on mobile robotics, especially path planning algorithms for mobile robots in uknown environment.

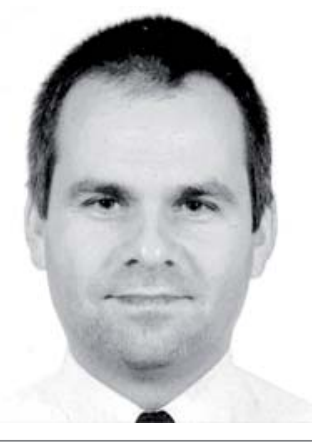

\section{Maciej Ciurej, MSc Eng.}

\section{Maciej.ciurej@gmail.com}

Graduated (2015) from the AGH University of Science and Technology. He is a PhD student at Faculty of Electrical Engineering, Automatics, Computer Science and Biomedical Engineering of AGH UST. His current research interests include: mobile robotics, artificial intelligence and machine learning.

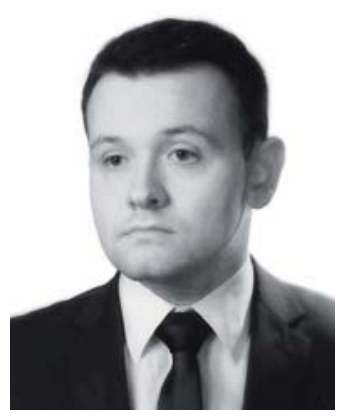

